\title{
Assessed versus Perceived Risks: Innovative Communications in Agri-Food Supply Chains
}

\author{
Fabio G. Santeramo*(D), Antonio Bevilacqua (D), Mariangela Caroprese, Barbara Speranza, \\ Maria Giovanna Ciliberti, Marco Tappi and Emilia Lamonaca (D)
}

Department of Agriculture, Food, Natural Resources and Engineering (DAFNE), University of Foggia,

71122 Foggia, Italy; antonio.bevilacqua@unifg.it (A.B.); mariangela.caroprese@unifg.it (M.C.); Barbara.speranza@unifg.it (B.S.); maria.ciliberti@unifg.it (M.G.C.); marco.tappi@unifg.it (M.T.); emilia.lamonaca@unifg.it (E.L.)

* Correspondence: fabio.santeramo@unifg.it; Tel.: +39-0881-589-349

check for

updates

Citation: Santeramo, F.G.;

Bevilacqua, A.; Caroprese, M.;

Speranza, B.; Ciliberti, M.G.; Tappi,

M.; Lamonaca, E. Assessed versus

Perceived Risks: Innovative

Communications in Agri-Food

Supply Chains. Foods 2021, 10, 1001

https://doi.org/10.3390/

foods10051001

Academic Editor: Bahar Aliakbarian

Received: 3 March 2021

Accepted: 30 April 2021

Published: 3 May 2021

Publisher's Note: MDPI stays neutral with regard to jurisdictional claims in published maps and institutional affiliations.

Copyright: (C) 2021 by the authors Licensee MDPI, Basel, Switzerland. This article is an open access article distributed under the terms and conditions of the Creative Commons Attribution (CC BY) license (https:/ / creativecommons.org/licenses/by/ $4.0 /$ )

\begin{abstract}
Food preparations, especially those based on animal products, are often accused of being responsible for the increase in food-borne infections, contributing to increased pressure on healthcare systems. The risk assessment in agri-food supply chains is of utmost importance for the food industry and for policymakers. A wrong perception of risks may alter the functioning of supply chains; thus, efforts should be devoted to communicating risks in an efficient way. We adopt a multidisciplinary approach to investigate how consumers perceive different food risks. Our analysis shows that planning effective communication strategies is very much important for efficiently informing consumers on food risks. We also comment on potential innovative ways to better organise the supply chains.
\end{abstract}

Keywords: food-borne illness; food safety; hazard; information; willingness to pay

\section{Introduction}

Foodborne diseases are becoming more and more frequent; depending on the type of pathogen involved, virulence, and individual state of health, they may cause morbidity and mortality worldwide [1]. In 2010, there were about 600 million foodborne disease cases and 420,000 related deaths. Viruses, bacteria, protozoa, and toxins (among other pathogens) may be passed throughout food supply chains and transferred to the consumers. In some cases, they may cause several symptoms and syndromes such as fever, diarrhea, sepsis, haemolytic uraemic syndrome, and diseases such as central nervous system infections, enteric intoxications, and hepatocellular carcinoma, or also lead to death [2]. One may argue that, due to these concerns, a solution may be to limit industrial production and adopt much more stringent standards, even if this would limit the amount of produced food. Unfortunately, this would be a rather partial, if not unfeasible, solution, as the production of food is only partially sufficient. Differently, the solution would be to produce enough food, but guarantee that it will be safe: the well-known pillars of food security [3]. The dual challenge is to ensure food safety so that the handling, preparation, and storage of food are respectful of protocols and hygienic practices to limit foodborne diseases [4] while reaching the food security status. This would ensure that safe food meets the need for healthy diets [5]. Food safety may be guaranteed through proper personal hygiene, appropriate storage, procuring food from safe sources, and cooking it at adequate temperatures [6]. Apart from the well-known thermal treatments, there are novel approaches, such as the use of ultrasounds combined with antimicrobials, that tend to be used to monitor the development of foodborne bacteria in the food industry [7]. The level of food safety may be also improved by means of policy interventions and investments to improve the transportation and communication infrastructures [8]. On the consumers' side, the challenge is to communicate the potential risks in an effective way to limit the risks 
associated with the consumption of contaminated or badly prepared foods. Unfortunately, it seems that consumers tend to underestimate food safety risks due to an optimistic bias, resulting in a misperception of specific hazards [9]. Consumers' choices are affected by several factors [10-12]: biological (e.g., taste), psychological (e.g., mood), physiological (e.g., access, time), social (e.g., culture, socio-cultural position), economics (e.g., cost, price, income), environmental and health factors, origin of food or animal production systems, and welfare. In short, food-risk perception is an important part of consumers' decision-making process and calls for a deep understanding of the mechanisms behind food communications $[13,14]$.

Following a multidisciplinary approach, the article deepens understanding of how different sources and types of risks tend to be perceived by consumers to draw conclusions on how information may be correctly and efficiently transferred to them. In particular, the article explores the effectiveness of communication in agri-food systems and comments on potential innovative ways to better organise the supply chains.

The next section of the article reviews potential risks for selected products of the agri-food industry (e.g., dairy and meat sector, fruit and vegetable sector). Section 3 explores methods to evaluate food risks and assess the risk level associated with different combinations of hazards and food products. Section 4 briefly reviews the literature on the role played by ambiguity aversion on decisions under uncertainty with specific emphasis on the potential role it plays in consumers' choices. Section 5 evaluates, through an experimental survey, how different sources and types of risks in selected agri-food supply chains are perceived by consumers. The last section concludes the article by providing insights on the role of innovative strategies to communicate risks in agri-food supply chains in an effective way to contribute to matching assessed with perceived food risks.

\section{Sources and Types of Risks for Selected Produce of Food Industry}

Foods based on animal derivates are common and consumers are concerned about the possibility of developing antimicrobial resistance. In 2011, the European Commission introduced a five-year action plan to face the rising threats from antimicrobial resistance and develop holistic measures to limit the use of antimicrobials, in particular in dairy animals. Animal-based foods are often accused of being responsible for the increase in foodborne infections [15]. Salmonella spp. and Escherichia coli are pathogens most frequently detected in food-borne outbreaks [16,17], as shown in Table 1. In 2017, the European Union reported 91,662 confirmed human cases of salmonellosis and 6073 Escherichia coli infections produced by the Shiga toxin (STEC): 19.7 infections per 100,000 individuals were notified for salmonellosis and 1.66 per 100,000 individuals for STEC infection [18].

Table 1. Reported cases due to zoonoses in the European Union, 2017.

\begin{tabular}{ccccc}
\hline Disease & $\begin{array}{c}\text { Confirmed } \\
\text { Cases }\end{array}$ & $\begin{array}{c}\text { Hospitalised } \\
\text { Cases }\end{array}$ & $\begin{array}{c}\text { Case Fatality } \\
\mathbf{( \% )}\end{array}$ & $\begin{array}{c}\text { Cases per 100,000 } \\
\text { Individuals (\%) }\end{array}$ \\
\hline Salmonellosis & 91,662 & 16,796 & 0.25 & 19.70 \\
STEC infection & 6073 & 933 & 0.50 & 1.66 \\
\hline
\end{tabular}

Source: Elaboration on EFSA and ECDC [18]. Notes: STEC stands for Shiga toxin-producing Escherichia coli.

Eggs are a main ingredient in several food products: about $70 \%$ of complex foods including eggs as an ingredient are associated with illness [19]. Eggs and egg products account for $36.8 \%$ of total salmonellosis, bakery products for $16.7 \%$, and meat and meat products for $8.2 \%$ of total salmonellosis [18]. Red meat contributes heavily to deaths associated with food-borne infections, despite lower levels of risk [15]. Outbreaks caused by STEC infection are mostly related to meat and its derivates, in particular, bovine meat and products account for $44.4 \%$, other meat and related products for $11.1 \%$, and milk for $22.2 \%$ of total STEC infection [18].

Food-borne infections are also caused by vegetable-based food products. Listeria monocytogenes and Clostridium botulinum are other sources of food-borne disease. They are 
related to the strongest case fatality among food-borne diseases, i.e., $7.7 \%$ for Clostridium botulinum and 5.1\% for Listeria monocytogenes [18]. In 2017, the EU reported 2480 cases of listeriosis. The rate was 0.48 per 100,000 individuals and the case fatality was $13.8 \%$. Fruit, vegetables, and their derivates account for $28.6 \%$ of total listeriosis disease [20]. Cases of botulism in the EU are approximately 200 per year (0.03 cases per 100,000 individuals) [21]. Primary causes of botulism are home preservation, traditional preservation, or failure of a commercial process [22].

\section{Evaluation of Food Risks}

According to Coleman and Marks [23], the probability and severity of diseases are highly related to characteristics of three factors and their interactions: the pathogen, such as species, virulence, dose, and growth potential in food (leftward angle in Figure 1); the host, such as health state and age (upward angle in Figure 1); and the environment, such as type of food vehicle and microbial competitors (rightward angle in Figure 1).

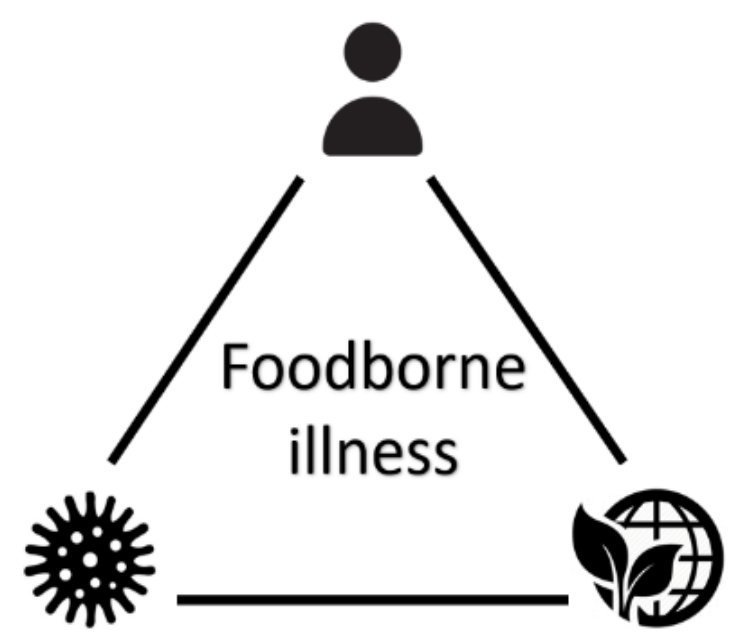

Figure 1. The epidemiology triangle. Source: Authors' elaboration on Coleman and Marks [23]. Notes: The triangle reports the pathogen in the leftward angle, the host in the upward angle, the environment in the rightward angle.

Several tools allow assessment of whether a pathogen may be a source of hazard for a certain food in a specific food process. Differently from semi-quantitative scoring systems and decision trees [24-26], stepwise approaches [27], and schemes for qualitative risk assessments [28,29], the Risk Ranger software allows identification of phases where control measures could be effectively implemented. Described in Ross and Sumner [30], the Risk Ranger software is a calculation tool based on 11 questions that allow attribution of a rank to a specific combination of food and hazard. The questions are related to the three main determinants of risk from a pathogen or toxin in a particular food product, i.e., the severity of the hazard, the dose of the hazard in a food causing the hazard, and the exposure to the hazard in a period.

The severity of the hazard depends on characteristics of the pathogen or toxin and on consumers' susceptibility: these aspects are analysed through questions 1 and 2. Questions 3-5 allow evaluation of the absolute risk (i.e., the dose of the hazard in a food causing the hazard) as a function of the consumption frequency, the proportion of individuals consuming the product, and the size of the population of interest. The exposure to the hazard is assessed considering aspects related to the contamination of food in questions 6-9 and question 11 and the concentration of the hazard in question 10.

Qualitative information collected from the 11 questions are converted into numerical values and combined with quantitative inputs to generate indices of risk ranging between 0 (i.e., no risk) and 100 (i.e., all products contain a lethal dose of the hazard). 
We used the Risk Ranger software to generate a Risk Ranking (RR) for 5 combinations of hazard and product (Table 2).

Table 2. Risk assessment from target food-borne risk factors in selected carriers.

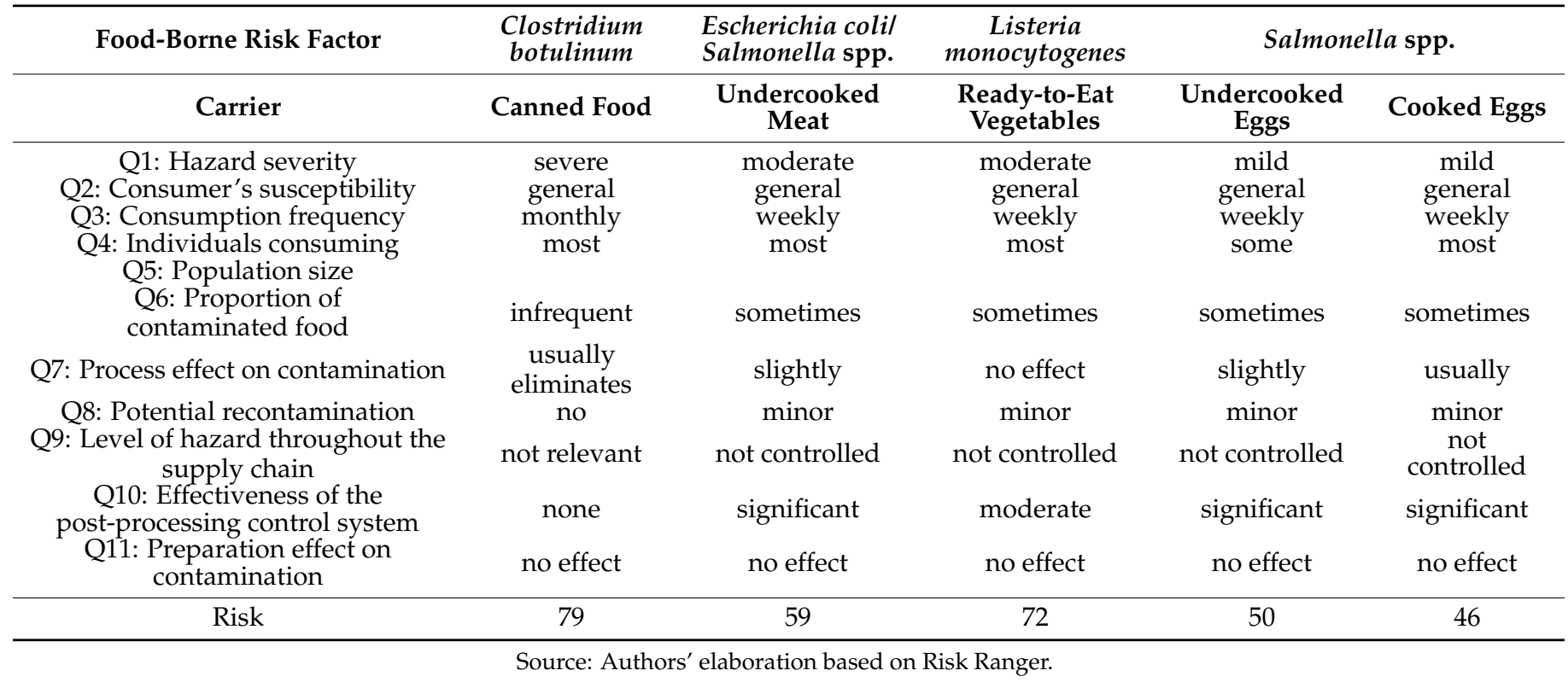

The hazard/product combinations analysed include Clostridium botulinum in canned food ( $R R=79)$, Escherichia coli or Salmonella spp. in undercooked meat $(R R=59)$, Listeria monocytogenes in ready-to-eat vegetables $(R R=72)$, Salmonella spp. in undercooked eggs $(R R=50)$, and Salmonella spp. in cooked eggs $(R R=46)$. Based on their ranking, those hazard/product pairs fall into a high-risk category $(>48)$.

As part of semi-quantitative methods, the risk matrix (Table 3) combines categorical labels (e.g., likelihood and severity) as possible semi-quantitative risk characterisations to determine the appropriate categorisation of the risk [31].

Table 3. Risk matrix.

\begin{tabular}{cccccc}
\hline Labels & Negligible & Minor & Moderate & Significant & Severe \\
\hline Very likely & $* *$ & $* * *$ & $* * * *$ & $* * * * *$ & $* * * * *$ \\
Likely & $*$ & $* *$ & $* * *$ & $* * * * *$ & $* * * * *$ \\
Possible & $*$ & $* *$ & $* * *$ & $* * *$ & $* * * *$ \\
Unlikely & $*$ & $* *$ & $* *$ & $* * *$ & $* * * *$ \\
\hline
\end{tabular}

Notes: The risk matrix combines the likelihood and severity of risks at different value scales that correspond to low risk $\left({ }^{*}\right)$, low-middle risk $\left({ }^{* *}\right)$, middle risk $\left({ }^{* *}\right)$, middle-high risk $\left({ }^{* * *}\right)$, and high risk $\left({ }^{* * * *}\right)$.

\section{Decisions under Uncertainty: Ambiguous and Innovative Communication Strategies}

Decisions under uncertainty are highly related to subjective determinants and characteristics of consumers and to the type of information they receive [32]. Communication in agri-food supply chains tends to be characterised by ambiguity: consumers have different capabilities in processing information (i.e., subjective factors) and are only partially informed on potential risks associated with certain foods as compared to producers and marketers (i.e., type of information). Ambiguity affects consumers' behaviours [33]. The way consumers make choices under uncertainty is affected by channels through which information is conveyed and by processes associated with the elaboration of information received. Indeed, communication strategies about risks in agri-food supply chains may influence consumers' attitudes and behaviours towards risky decisions [14]. 
A recent paper by Santeramo and Lamonaca [15] evaluated how food risks are perceived to emphasise how food-safety information may be efficiently communicated to consumers. According to Grunert [34], there is a mismatch between assessed risks and perceived risks in agri-food supply chains. Food risks may be assessed considering two objective and scientific dimensions: the severity of the hazard and the likelihood of risk occurrence [35]. However, food risks may be differently perceived by consumers depending on their degree of aversion towards hazards and risks. The degree of aversion may depend on awareness of a certain food risk that may be known or unknown and on concern related to potential adverse effects of consuming unsafe food that counterpose not-dreadful and dreadful food-borne risks [36]. Based on these premises, Santeramo and Lamonaca [15] elaborated a conceptual framework and classify food-borne risk factors analysed in literature according to objective (i.e., assessed risks) and subjective (i.e., perceived risks) dimensions (Figure 2).

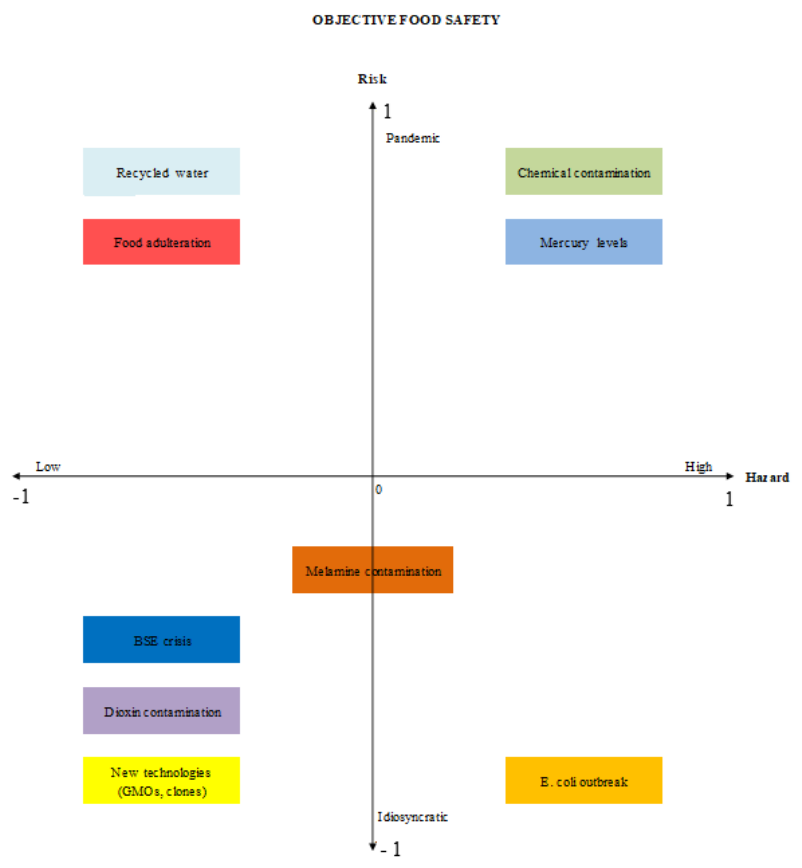

(a)

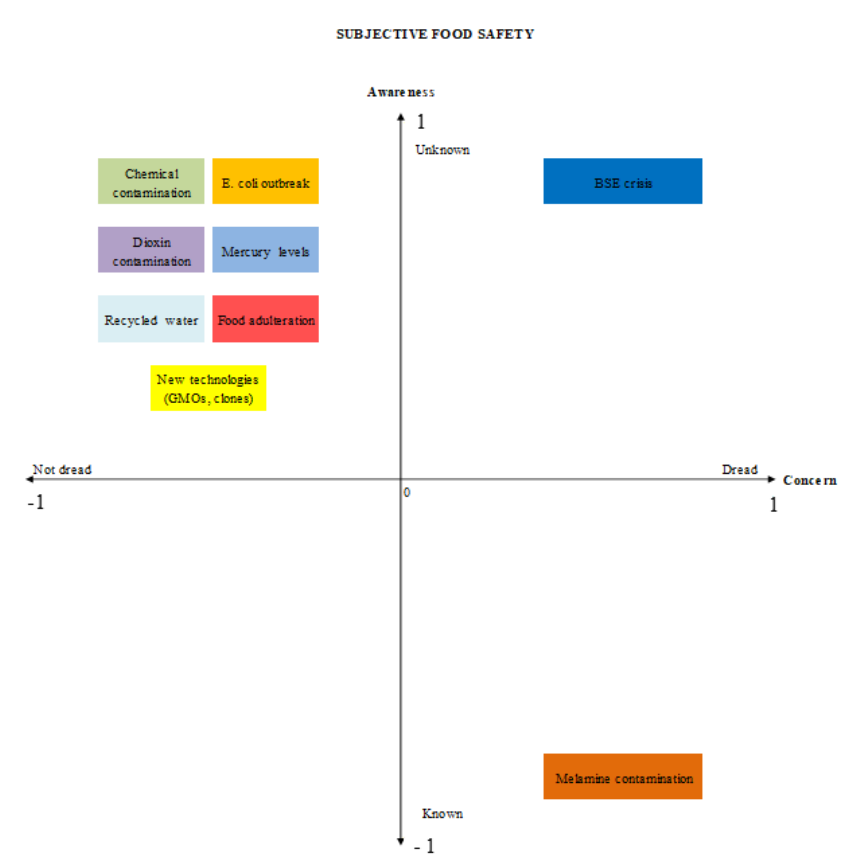

(b)

Figure 2. Conceptual framework elaborated in Santeramo and Lamonaca [15] to classify food-born factors. Panel (a) considers the objective dimensions of food safety. Panel (b) considers the subjective dimensions of food safety. Source: Santeramo and Lamonaca [15].

As evident from Figure 2, there is a frequent inconsistency between assessed and perceived risks in agri-food systems. The discrepancy mostly occurs in the case of food scares. A few examples are mad cow disease (BSE crisis) or dioxin contamination. Divergences between assessed and perceived food risks are also common for new technologies (e.g., GMOs, clones).

The meta-analysis by Santeramo and Lamonaca [15] also concluded on the role that communication strategies may have in reducing the gap between assessed and perceived food risks. The meta-regression results reveal that products conveying food-safety information through labels benefit from a price premium of the magnitude of $+169 \%$. It should be not neglected that, if exposed to relevant food risk information, risk perception tends to be alienated from assessed risk and decision-makers tend to reduce premium prices [32,37]. To overcome this problem, producers and marketers in agri-food supply chains should consider innovative strategies to improve the communication of food risks, avoiding losing premium prices for food safety information. Examples are innovative labels conveying 
information on food safety, such as traffic lights labels and nutri-score labels, or the use of nanotechnologies [38].

\section{Consumers' Perception of Sources and Types of Risks}

An experimental survey has been developed to evaluate how consumers perceive food risks and emphasise how food safety information may be effectively communicated to consumers. Based on the review of sources and types of risks and on evidence from the Risk Ranger analysis, the following food-safety risks posed by specific hazard/product combinations have been considered:

1. botulism from Clostridium botulinum in canned food;

2. haemolytic uremic syndrome from Escherichia coli in undercooked meat;

3. listeriosis from Listeria monocytogenes in ready-to-eat vegetables;

4. salmonellosis from Salmonella spp. in under-cooked eggs.

The experimental design involved three information treatments synthesised in Table 4. In the first stage, respondents received only general information to establish a baseline level of understanding about each hazard/product combination. In the second stage, respondents received partial information linking each hazard to a food-borne disease. In the third stage, we exposed respondents to a negative and a positive message (complete information). While the negative message informed consumers on symptomatology associated with each food-borne disease, the positive message communicated that consumers may significantly reduce the risk of a food-borne infection by adopting specific prevention measures.

Table 4. Information treatments.

\begin{tabular}{cccc}
\hline Food-Borne Risk Factor & General Information & Partial Information & Complete Information \\
\hline Clostridium botulinum & May be present in canned food & May cause botulism & May cause haemolytic uremic \\
Escherichia coli & May be present in undercooked meat & $\begin{array}{c}\text { Symptoms and prevention } \\
\text { measures }\end{array}$ & May cause listeriosis \\
Listeria monocytogenes & May be present in & ready-to-eat vegetables & May cause salmonellosis \\
Salmonella spp. & May be present in undercooked eggs & May & \\
\hline
\end{tabular}

Source: elaboration on information from EpiCentro 2020 [39-42].

The questionnaire, preliminarily tested among selected respondents, was available from July to December 2020 as a Google Form and shared via social networks (e.g., Facebook, LinkedIn, Twitter) and e-mail lists (e.g., professional associations, producers' groups, consumers groups). Adopting a snowball sampling recruitment allowed us to take advantage of interpersonal relations and connections among respondents. The sample consists of 166 young Italian consumers (18-35 years old). Figure 3 shows the self-reported knowledge of food-borne risk factors and the frequency of consumption of selected food products.

Respondents frequently consume ready-to-eat vegetables (more than 3 times per month) and canned food (2-3 times per month or more); under-cooked meat and eggs are consumed less. Escherichia coli and Listeria monocytogenes are known to $61 \%$ of respondents, whereas Clostridium botulinum and Salmonella spp. are known only to 39\% and 38\% of respondents, respectively. 


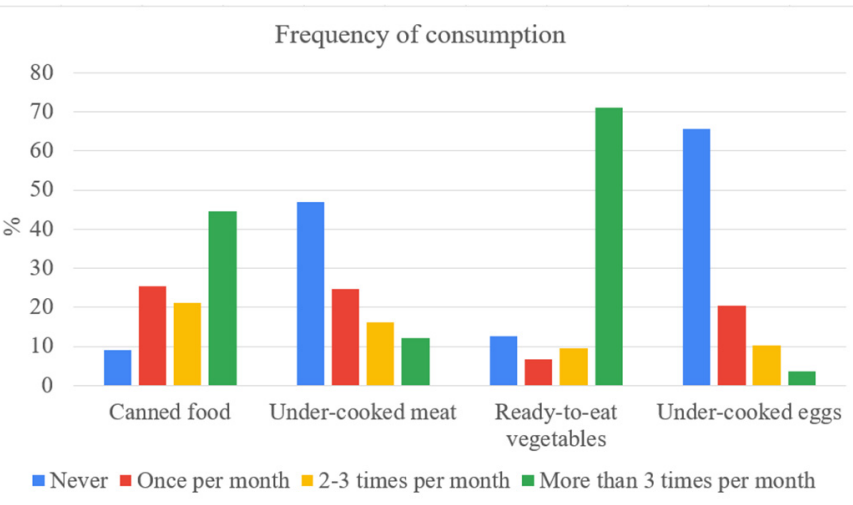

(a)

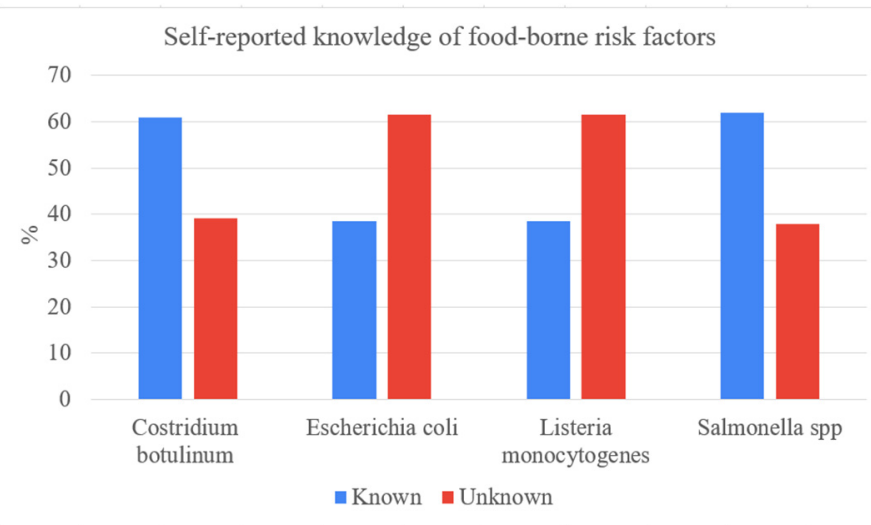

(b)

Figure 3. Panel (a) reports the frequency of consumption of food products. Panel (b) shows the self-reported knowledge of food-borne risk factors.

In each stage (i.e., information treatments), respondents were asked to assess the risk of consuming selected foods and to specify the premium price they are willing to pay for microbiologically tested food. The results (Table 5) reveal that, moving from general to partial information, the perceived risk is unchanged for each hazard/product combination. With partial information, the match between perceived risk and assessed risk (see Table 2) occurs only for Escherichia coli in undercooked meat and Salmonella spp. in under-cooked eggs. Moving from partial to complete information, the perception of risks associated with the combinations Clostridium botulinum/canned food and Listeria monocytogenes / ready-to-eat vegetables increases but does not correspond to assessed risks.

Table 5. Assessed versus perceived risks.

\begin{tabular}{cccccc}
\hline Food-Borne & Product & Assessed & & \multicolumn{2}{c}{ Perceived Risk } \\
\cline { 4 - 6 } Risk Factor & Risk & $\begin{array}{c}\text { General } \\
\text { Information }\end{array}$ & $\begin{array}{c}\text { Partial } \\
\text { Information }\end{array}$ & $\begin{array}{c}\text { Complete } \\
\text { Information }\end{array}$ \\
\hline $\begin{array}{c}\text { Clostridium botulinum } \\
\text { Escherichia coli } \\
\text { Listeria }\end{array}$ & $\begin{array}{c}\text { Canned food } \\
\text { Under-cooked meat }\end{array}$ & $79 \%$ & $20-40 \%$ & $20-40 \%$ & $40-60 \%$ \\
Ready-to-eat & $59 \%$ & $40-60 \%$ & $40-60 \%$ & $40-60 \%$ \\
Salmocytogenes & $\begin{array}{c}\text { vegetables } \\
\text { Under-cooked eggs }\end{array}$ & $72 \%$ & $40 \%$ & $40 \%$ & $40-60 \%$ \\
\hline
\end{tabular}

Notes: average values for subjective risks.

Moving from partial to general information, the willingness-to-pay (WTP) for microbiologically tested products is unchanged. The only exception is the combination Clostridium botulinum/canned food with a one-percent increase in WTP (from 7\% to 8\%) (Table 6).

Table 6. Willingness to pay for microbiologically tested products.

\begin{tabular}{cccc}
\hline $\begin{array}{c}\text { Food-Borne } \\
\text { Risk Factor }\end{array}$ & Product & $\begin{array}{c}\text { Partial } \\
\text { Information }\end{array}$ & $\begin{array}{c}\text { Complete } \\
\text { Information }\end{array}$ \\
\hline Clostridium botulinum & $\begin{array}{c}\text { Canned food } \\
\text { Escherichia coli }\end{array}$ & $7 \%$ & $8 \%$ \\
Listeria monocytogenes & Ready-to-eat vegetables & $8 \%$ & $8 \%$ \\
Salmonella spp. & Under-cooked eggs & $8 \%$ & $8 \%$ \\
\hline
\end{tabular}

Control questions showed that only a low percentage of respondents correctly processed information provided in each treatment. This evidence highlights the need to revise the experimental design to correctly convey information to respondents. 


\section{Concluding Remarks}

We examined the role of communication in food supply chains and how it may contribute to matching assessed with perceived risks and avoiding biases due to ambiguity aversion in consumers' choices. In particular, the review of different sources and types of risks for selected food industries highlighted the incidence of food-borne infections in animal-based foods, such as meat (especially undercooked meat) and eggs and egg products (especially under-cooked eggs), as well as in ready-to-eat vegetables and canned food (especially homemade preparations). In addition, the approach used to predict food risks (i.e., Risk Ranger software) allowed identification of the assessed risk (RR) in selected hazard/product combinations, i.e., Clostridium botulinum in canned food $(\mathrm{RR}=79)$, Escherichia coli in undercooked meat $(\mathrm{RR}=59)$, Listeria monocytogenes in ready-to-eat vegetables $(R R=72)$, and Salmonella spp. in under-cooked eggs $(R R=56)$. Further, the role the reviewed literature played in assessing ambiguity aversion on decisions made under uncertainty revealed that, if consumers receive information on potential risks associated with the consumption of unsafe food, their risk perception increases, and their willingness to pay premium prices for information on food safety decreases.

Based on this evidence, an experimental survey aimed at evaluating how different sources and types of risks are perceived by consumers emphasised that communication in food supply chains plays a relevant role. However, the information on assessed risk is efficiently transferred to consumers only for specific hazard/product combinations, i.e., Escherichia coli in undercooked meat and Salmonella spp. in under-cooked eggs.

Implications for the food industry and policymakers are derived. Food safety in agri-food supply chains is frequently characterised by asymmetric information. Producers and marketers tend to be better informed than consumers on the potential risks of foods. Particularly relevant is the gap between assessed and perceived risks related to Clostridium botulinum in canned food and Listeria monocytogenes in ready-to-eat vegetables. Using innovative strategies to communicate information on food risks may contribute to lowering the divergence between assessed and perceived risks. In this regard, innovative labels, such as traffic lights labels and nutri-score labels, or the use of nanotechnologies may be a valid alternative. Furthermore, technologies such as Agri-Food 4.0, Blockchain, and Internet of Things may be useful tools to inform consumers in real-time, also supporting the supply chain decision-making process [43] and improving the coordination process that involves farmers, industries, and consumers [44].

Nonetheless, correctly conveying the information is challenging and needs to be further investigated. This emerges also from the results of the experimental survey (i.e., only a low percentage of respondents correctly processed information). To overcome this limitation, further research is needed to reorganise the structure of the experimental design to provide further types of information. Further research in this direction would provide a clearer understanding of how consumers assess food-safety risks and how much they are willing to pay for labels indicating safe food.

Author Contributions: Conceptualization, A.B. and M.C.; methodology, B.S., M.G.C. and E.L.; software, B.S.; validation, A.B. and M.C.; formal analysis, E.L.; investigation, A.B. and M.C.; resources, M.G.C.; data curation, M.T.; writing—original draft preparation, M.T.; writing—review and editing, E.L.; visualization, M.T.; supervision, F.G.S.; project administration, F.G.S.; funding acquisition, F.G.S. All authors have read and agreed to the published version of the manuscript.

Funding: This research was funded by University of Foggia (Italy), granted projects "Objective Risks, Subjective Risks, and Ambiguity: the role of Communication in Food Supply Chains (OSRAC in S.C.)".

Data Availability Statement: Not applicable.

Acknowledgments: The authors are grateful to Clelia Altieri, Marzia Albenzio, Antonio Seccia, Biagia De Devitiis, Rosaria Viscecchia, and Maria Rosaria Corbo for supporting the development of the project and for helpful comments. 
Conflicts of Interest: The authors declare no conflict of interest.

\section{References}

1. Finger, J.A.; Baroni, W.S.; Maffei, D.F.; Bastos, D.H.; Pinto, U.M. Overview of foodborne disease outbreaks in Brazil from 2000 to 2018. Foods 2019, 8, 434. [CrossRef]

2. WHO. WHO Estimates of the Global Burden of Foodborne Diseases: Foodborne Disease Burden Epidemiology Reference Group 2007-2015. 2015. Available online: https:/ / apps.who.int/ (accessed on 13 January 2021).

3. Santeramo, F.G. On the composite indicators for food security: Decisions matter! Food Res. Int. 2015, 31, 63-73. [CrossRef]

4. Augustin, J.C.; Kooh, P.; Bayeux, T.; Guillier, L.; Meyer, T.; Silva, J.D.; Villena, I.; Sanaa, M.; Cerf, O. Contribution of Foods and Poor Food-Handling Practices to the Burden of Foodborne Infectious Diseases in France. Foods 2020, 9, 1644. [CrossRef] [PubMed]

5. Redmond, E.C.; Griffith, C.J. Consumer perceptions of food safety risk, control and responsibility. Appetite 2004, 43, 309-313. [CrossRef]

6. McCabe-Sellers, B.J.; Beattie, S.E. Food safety: Emerging trends in foodborne illness surveillance and prevention. J. Am. Diet. Assoc. 2004, 104, 1708-1717. [CrossRef] [PubMed]

7. Bevilacqua, A.; Speranza, B.; Iorio, M.C.; Loi, M.; Sinigaglia, M.; Corbo, M.R. US-inactivation of foodborne bacteria: Screening in distilled water and combination with citrus extract in skim milk. LWT Food Sci. Technol. 2016, 70, 135-141. [CrossRef]

8. Schmidhuber, J.; Tubiello, F.N. Global food security under climate change. Proc. Natl. Acad. Sci. USA 2007, 104, 19703-19708. [CrossRef] [PubMed]

9. Walls, H.; Baker, P.; Chirwa, E.; Hawkins, B. Food security, food safety \& healthy nutrition: Are they compatible? Glob. Food Secur. 2019, 21, 69-71.

10. Santeramo, F.G.; Carlucci, D.; De Devitiis, B.; Seccia, A.; Stasi, A.; Viscecchia, R.; Nardone, G. Emerging trends in European food, diets and food industry. Food Res. Int. 2018, 104, 39-47. [CrossRef]

11. Caroprese, M.; Ciliberti, M.G.; Marino, R.; Napolitano, F.; Braghieri, A.; Sevi, A.; Albenzio, M. Effect of information on geographical origin, duration of transport and welfare condition on consumer's acceptance of lamb meat. Sci. Rep. 2020, 10, 1-10. [CrossRef]

12. Wongprawmas, R.; Mora, C.; Pellegrini, N.; Guiné, R.P.; Carini, E.; Sogari, G.; Vittadini, E. Food Choice Determinants and Perceptions of a Healthy Diet among Italian Consumers. Foods 2021, 10, 318. [CrossRef]

13. Cope, S.; Frewer, L.J.; Houghton, J.; Rowe, G.; Fischer, A.R.H.; de Jonge, J. Consumer perceptions of best practice in food risk communication and management: Implications for risk analysis policy. Food Policy 2010, 35, 349-357. [CrossRef]

14. Frewer, L.J.; Fischer, A.R.H.; Brennan, M.; Bánáti, D.; Lion, R.; Meertens, R.M.; Rowe, G.; Siegrist, M.; Verbeke, V.; Vereijken, C.M.J.L. Risk/benefit communication about food-A systematic review of the literature. Crit. Rev. Food Sci. 2016, 56, 1728-1745. [CrossRef]

15. Santeramo, F.G.; Lamonaca, E. Objective risk and subjective risk: The role of information in food supply chains. Food Res. Int. 2021, 139, 109962. [CrossRef] [PubMed]

16. Godwin, S.; Maughan, C.; Chambers, E. Food safety: Recommendations for determining doneness in consumer egg dish recipes and measurement of endpoint temperatures when recipes are followed. Foods 2016, 5, 45. [CrossRef]

17. Panea, B.; Ripoll, G. Quality and Safety of Meat Products. Foods 2020, 9, 803. [CrossRef]

18. EFSA; ECDC. The European Union summary report on trends and sources of zoonoses, zoonotic agents and food-borne outbreaks in 2017. EFSA J. 2018, 16, e05500.

19. Adak, G.K.; Meakins, S.M.; Yip, H.; Lopman, B.A.; O’Brien, S.J. Disease risks from foods, England and Wales, 1996-2000. Emerg. Infect. Dis. 2005, 11, 365. [CrossRef] [PubMed]

20. EFSA; ECDC. The European Union one health 2018 zoonoses report. EFSA J. 2019, 17, e05926.

21. ECDC. Facts about Botulism. European Centre for Disease Prevention and Control. 2017. Available online: https://www.ecdc. europa.eu/ (accessed on 1 October 2020).

22. EFSA. Opinion of the Scientific Panel on biological hazards (BIOHAZ) related to Clostridium spp in foodstuffs. EFSA J. 2005, 3 , 199. [CrossRef]

23. Coleman, M.; Marks, H. Topics in dose-response modeling. J. Food Prot. 1998, 61, 1550-1559. [CrossRef]

24. Notermans, S.; Mead, G.C. Incorporation of elements of quantitative risk analysis in the HACCP system. Int. J. Food Microbiol. 1996, 30, 157-173. [CrossRef]

25. Todd, E.C.; Harwig, J. Microbial risk analysis of food in Canada. J. Food Prot. 1996, 59, 10-18. [CrossRef]

26. Van Schothorst, M. Practical approaches to risk assessment. J. Food Prot. 1997, 60, 1439-1443. [CrossRef]

27. Van Gerwen, S.J.C.; Te Giffel, M.C.; Van't Riet, K.; Beumer, R.R.; Zwietering, M.H. Stepwise quantitative risk assessment as a tool for characterization of microbiological food safety. J. Appl. Microbiol. 2000, 88, 938-951. [CrossRef] [PubMed]

28. Corlett, D.A.; Pierson, M.D. Hazard analysis and assignment of risk categories. In HACCP; Springer: Boston, MA, USA, 1992; pp. 29-38.

29. Huss, H.H.; Reilly, A.; Embarek, P.K.B. Prevention and control of hazards in seafood. Food Control 1992, 11, 149-156. [CrossRef]

30. Ross, T.; Sumner, J.A. Simple, spreadsheet-based, food safety risk assessment tool. Int. J. Food Microbiol. 2002, 77, 39-53. [CrossRef]

31. FAO; WHO. Joint FAO/WHO Expert Meetings on Microbiological Risk Assessment (JEMRA) on Methodologies of Microbiological Risk Assessment; FAO/WHO: Rome, Italy, 2019; In press. 
32. Cao, Y.; Just, D.R.; Turvey, C.; Wansink, B. Existing food habits and recent choices lead to disregard of food safety announcements. Can. J. Agr. Econ. 2015, 63, 491-511. [CrossRef]

33. Fox, C.R.; Tversky, A. Ambiguity aversion and comparative ignorance. Q. J. Econ. 1995, 110, 585-603. [CrossRef]

34. Grunert, K.G. Food quality and safety: Consumer perception and demand. Eur. Rev. Agric. Econ. 2005, 32, 369-391. [CrossRef]

35. Henson, S.; Traill, B. The demand for food safety: Market imperfections and the role of government. Food Policy 1993, 18, 152-162. [CrossRef]

36. Slovic, P. Perception of risk. Science 1987, 236, 280-285. [CrossRef]

37. Britwum, K.; Yiannaka, A. Consumer willingness to pay for food safety interventions: The role of message framing and issue involvement. Food Policy 2019, 86, 101726. [CrossRef]

38. Santeramo, F.G.; Carlucci, D.; De Devitiis, B.; Viscecchia, R.; Nardone, G. The (Nano-) Discrimination of Consumers for NanoInside Technologies. J. Int. Food Agric. Mark. 2020, 1-15. [CrossRef]

39. EpiCentro. Botulismo Alimentare. L'epidemiologia per la Sanità Pubblica—Istituto Superiore di Sanità. 2020. Available online: https:/ / www.epicentro.iss.it/botulismo/ (accessed on 16 November 2020).

40. EpiCentro. Sindrome Emolitico-Uremica. L'epidemiologia per la Sanità Pubblica-Istituto Superiore di Sanità. 2020. Available online: https:/ / www.epicentro.iss.it/seu/ (accessed on 4 December 2020).

41. EpiCentro. Listeria. L'epidemiologia per la Sanità Pubblica-Istituto Superiore di Sanità. 2020. Available online: https:/ / www.epicentro.iss.it/listeria/ (accessed on 15 October 2020).

42. EpiCentro. Salmonella. L'epidemiologia per la Sanità Pubblica-Istituto Superiore di Sanità. 2020. Available online: https: / / www.epicentro.iss.it/salmonella/ (accessed on 27 September 2020).

43. Lezoche, M.; Hernandez, J.E.; Díaz, M.D.M.E.A.; Panetto, H.; Kacprzyk, J. Agri-food 4.0: A survey of the supply chains and technologies for the future agriculture. Comput. Ind. 2020, 117, 103187. [CrossRef]

44. Handayati, Y.; Simatupang, T.M.; Perdana, T. Agri-food supply chain coordination: The state-of-the-art and recent developments. Logist. Res. 2015, 8, 1-15. [CrossRef] 